\title{
Jandarma Genel Komutanlığı'nın Sivil Kolluk Olarak Teşkilatlanması Sonrasında Oluşan Etkiler Üzerine Bir Değerlendirme $^{1 *}$
}

\author{
Fatih ERARSLAN \\ Öğr. Gör., Tokat Gaziosmanpaşa Üniversitesi, \\ Erbaa Meslek Yüksekokulu, Özel Güvenlik ve Koruma Programı \\ fatih.erarslan@gop.edu.tr \\ Orcid ID: https://orcid.org/0000-0003-2863-6310
}

\section{$\ddot{O} \mathbf{z}$}

$\mathrm{Bu}$ çalışmada; Jandarma Genel Komutanlığının askerî kolluk yapılanmasından, sivil kolluk sürecine geçişi sonrasında meydana gelen yönetimsel değişikliler ve etkilerinin ortaya konulması amaçlanmıştır. Jandarma Genel Komutanlığının teşkilat yapısı hakkında şu ana kadar yapılan çalışmalarda kurum askerî kolluk olarak incelenmekte iken bu çalş̧ma sivil kolluk yapılanmasının incelenmesine dair ilk çalışmalardan olduğu için önem taşımaktadır.

Çalışmanın hazırlanmasında ikincil veriler kullanılarak Jandarma Genel Komutanlığının kolluk yapılanması incelenmiş ve sivil kolluk olarak düzenlenmesini meydana getiren Kanun Hükmünde Kararnameler ile ortaya çıkan değişiklikler açıklanmaya çalışılmıştır. Sivil kolluk yapılanmasının oluşturduğu etkilerin belirlenmesi amacıyla 20 Emekli/Müstafi Jandarma Genel Komutanlığı personeli ile mülakat yapılmış ve elde edilen bulgular ışığında sonuç ve değerlendirme kısmı yazılmıştır.

Anahtar Kelimeler: Kamu Düzeni, Genel Kolluk, İç Güvenlik, Jandarma, Değişim.

${ }^{1}$ Makale Geliş/Kabul Tarihi: 07.12.2020/13.12.2021

* Bu makale "Jandarma Genel Komutanlı̆̆ı'nın Sivil Kolluk Olarak Teşkilatlanması Sonrasında Oluşan Etkiler Üzerine Bir Değerlendirme" başlıklı yüksek lisans tezinden üretilmiştir.

Künye Bilgisi: Erarslan, F. (2021). Jandarma Genel Komutanlığı'nın sivil kolluk olarak teşkilatlanması sonrasında oluşan etkiler üzerine bir değerlendirme. Kahramanmaraş Sütçü İmam Üniversitesi Sosyal Bilimler Dergisi, 18 (3), 2016-2042. DOI: 10.33437/ksusbd.836834. 


\title{
An Assessment Of The Effects Of Gendarmerie General Command After The Organization Of Civilian Law Enforcement
}

\begin{abstract}
In this study, it was aimed to bring out the administrative changes and effects of Gendarmerie General Command after the transition from military law enforcement to civilian law enforcement. This study is important; it is the first study on the investigation of the civilian law enforcement structure while the institution is being examined as a Military Police.

In the preparation of the study, the law enforcement structure of the Gendarmerie General Command was examined by using secondary sources, and the changes that emerged with the Decree Laws were tired to be explained. In order to determine the effects of the Civilian Law Enforcement structure, 20 Retired/Resigned Gendarmerie General Command personnel were interviewed.
\end{abstract}

Keywords: Public Order, Gendarmerie General Command, Internal Security, Gendarmerie, Changing/ Variation.

\section{GíRiş}

Toplum hayatının dirlik ve düzen içinde devam etmesinin en temel şartı güvenli bir ortamdır. Güvenliğin temelini oluşturan emniyet ve asayiş ise kolluk kuvvetleri aracılığıyla icra edilir. Kolluk dirlik, düzen ve güven duygusunu, toplumda yaygın inanış hâline getirmekle görevlidir.

Emniyet, devlete, topluma, kişilere, mal ve eşyalara yönelik sabotaj, tehlike ve kazaları önlemek için alınan hukuka uygun önlemlerin tümünü ve bu önlemlerin alınmış bulunduğu hali belirtir. Asayiş ise hukuka uygun ve gerekli önlemlerin alınması sonucu devlete, topluma, kişilere, mal ve eşyalara yönelik tehlike, kaza ve sabotajların söz konusu olmadığ bir ortamı, düzensizlik ve karışıklıkların önlendiği, hayatın normal akışının sağlandığı hali, dirlik ve düzenin varlı̆̆ konusunda kamuda yaratılan yerleşik ve yaygın inancı ifade eder (JOK, 2004: 2-13).

Günlük hayat akışında birlikte yaşayan insanlar birtakım nedenler ileri sürerek, toplumda mevcut olan kurallara aykırı hareket edebilirler. Böyle bir durumda güvenliğin sağlanması amacıyla, devletin temel hak ve özgürlüklerin sınırlı bir şekilde kullanılmasını gerçekleştirebilmek için gerek duyduğu maddî güç te kolluk kuvvetleri tarafindan sağlanmaktadır.

Jandarma Genel Komutanlığı (JGK) bu bağlamda emniyet ve asayişi sağlama ve kamu düzenini korumak maksadıyla Jandarma Teşkilât Görev ve Yetkileri 
Kanunu, Polis Vazife ve Salâhiyetleri Kanunu ve diğer kanunlarda belirtilen gerekli her türlü güvenlik tedbirlerini almaya yetkilidir. Jandarma, ülkemizin \%92'sinde görev yapan bir kolluk kuvvetidir. Sorumluluk alanı genelde kırsal bölgeleri, köy ve kasabaları kapsar. Kırsal kesimde yaşayan vatandaşlarımız için jandarma ulaşılması kolay ve hemen yakınında bulunan bir devlet kuruluşudur. Bu nedenle, geçmişte olduğu gibi günümüzde de köylü gözünde devlet kavramı, jandarmanın varlığı, ehliyeti, kanunî bilgisi ve vazife ifasındaki liyâkat ve yeterliliğiyle ölçülür. Halk, devlet denilince jandarmayı, jandarma denilince devleti tanır.

\section{KAVRAMSAL ÇERÇEVE}

\section{Kolluk Kavramı}

Toplum halinde hayat sürdürmek her şeyden önce o toplum içinde bir güven ve düzenin sağlanmasına ve devam ettirilmesine bağlıdır. Bu yüzden insanların düzen ve güven içinde yaşama ihtiyacı, özgürlük ihtiyacından daha eskidir (Yıldırım, 2010: 133). Bundan dolayıdır ki tarih boyunca hiçbir toplum düzensizliğe prim vermemiştir. Bir toplumda düzensizliğe firsat veren, göz yuman bir otorite boşluğu doğduğu zaman derhal düzeni sağlayan yeni bir otorite ortaya çıkmış ve toplum da yeni otoriteyi desteklemiştir (Kıratl1, 1973: 27). İnsanoğlunun dünyaya geldiği ilk andan itibaren güvenli bir ortamda bulunma ihtiyacı ortaya çıkmaktadır. Anne karnında başlayan ve toplum içerisinde devam eden hayatı boyunca doğal olarak sürdürülen huzur ortamı bozulduğu hallerde ortaya çıkan düzen oluşturma çabaları, bu işi yapacak olan güvenlik güçlerini zorunlu hale getirmektedir (Kahraman, 2013: 23).

Eski toplumlarda bile, idarenin sahip olduğu kamu gücünü kullanarak toplumdaki düzeni sağlamak ve korumak amaciyla hareket ettiği bilinmektedir. İdare başka bir deyişle devlet, kolluk gücünü (kamu gücünü) kullanarak bunları denetleyerek ve gerektiğin de bunlara müdahale ederek toplumdaki kamu düzenini sağlar (Giritli vd., 2013: 740).

Kolluk sistemi dünyada genel uygulanış biçimi olarak iki farklı yapıya sahiptir. Birincisi "Polis" diye adlandırılan sistemdir ve oluşumu uzun yıllar öncesine dayanmaktadır. Polis kelimesi Latince "politia=politika" sözcügüünden türemiş ve kent/şehir manasında kullanılmıştır. Daha sonra ise geniş anlamda kent teşkilatı ve devlet yönetimi gibi anlamlar için kullanılan Polis kelimesi günümüzde ise kent içinde kamu düzenini, huzur ve esenliği sağlayan örgüt, kolluk, zabıta anlamını kullanmaktadır. İkinci olarak ise "Askerî Statüye Sahip (Law-Enforcement)" yani askerî bir yapı içerisinde bulunup aynı zamanda sivil makamlar tarafından yönetilen bir kuvvet olan ve birçok ülke tarafından “Jandarma” olarak isimlendirilen kuvvettir. “Jandarma” kelimesine etimolojisi 
olarak bakıldığında Fransızcada kullanılan "gens d'armes" yani "silâhlı adamlar" kelimesinden geldiği söylenmektedir (Özalp, 2015: 11).

Kolluk kavramı idare hukukunda en geniş tanımlamalara sahip olan bir kavramdır. Çeşitli yazarlara göre kısmi farklılıklar içeren birçok kolluk tanımı mevcuttur. Yenisey (1991: 45) kolluk kavramını görev açısından; kamu düzeninin sağlanması, kamu güvenliğinin kollanması ve korunması, suçluların bulunması, suçun önlenmesi, gerektiğinde zor kullanma yetkisine sahip olan ve yetkileri kanunlarla çerçevelendirilen kamu kuruluşu, diğer bir deyişle; emniyet ve asayişin sağlanması amacıyla kanunların verdiği görevleri yerine getiren, yetkiler kullanan icra ve inzibat kuvveti olarak tanımlamaktadır.

Gözübüyük-Tan’a (1999: 472) göre ise kolluk bir taraftan, kamu düzenini oluşturan, muhafaza eden ya da kamu düzeni bozulduğunda eski durumunu tekrar sağlayan idari etkinlikler, diğer yandan da bu tür etkinlikleri yürüten görevliler anlamında kullanılır. Bir başka çalışmada ise kolluğu kamu makamları tarafından, kamu düzenini sağlamak gayesiyle kamu özgürlüklerine konulan sınırlamalar olarak tanımlamaktadır (Giritli vd., 2013: 741).

Yapılan tanımların sayısını arttırmak mümkündür. Yazarların kolluk kavramını farklı kelimelerle tarif etmelerine rağmen, anlam olarak hepsi birbirine yakındır. Tanımların odak noktası "kamu düzeni" dir. Tanımların bir diğer ortak yönü de kolluk kavramının fonksiyonel anlamda kolluk hizmetini; organik anlamda da bu hizmeti yerine getiren örgüt ve personeli ifade ettiğidir (Bucaktepe, 2008: 25).

\section{Kamu Düzeni}

Kamu düzeni bütün toplumların hayatlarında var olan bir kavramdır. Bu kavramın içeriği devletten devlete, dönemden döneme değişiklikler göstermesine rağmen her zaman özgürlüklerin kullanılmasına bir sınırlamanın getirilmesi olarak anlaşılmaktadır. Kamu düzeni zamana ve mekâna göre değişiklik göstermesinden dolayı genel geçerli bir tanımının yapılması oldukça güçtür. Anayasa Mahkemesi de bir kararında, kamu düzenin tanımının yapılmasının zorluğundan bahsettikten sonra, "kamu düzeni deyiminin toplumun huzur ve sükûnun sağlanmasını, devletin ve devlet teşkilatının muhafazasını hedef tutan her şeyi ifade ettiği, bir başka deyimle cemiyetin her sahada ki düzeninin temelini teşkil eden bütün kuralları kapsadığı sonucuna varılmaktadır." biçiminde bir tanımlama yapmıştır (Yıldırım, 2010: 135).

Türk hukuk literatüründe kamu düzenine ve kamu düzenini oluşturan unsurlara yer veren birçok kural vardır. Anayasamızda ve çeşitli kanunlarda kamu düzeni, genel sağlık, genel ahlak, umumi emniyet ve asayiş, kamu güvenliği, genel güvenlik, halkın $1 \mathrm{rz}$, can ve malını muhafaza, ammenin 
istirahatini temin gibi kavramlar yer almaktadır. Kamu düzeni, literatürde en çok kullanılan kavramlardan biri olmasına rağmen tanımlanması hayli zordur (Bucaktepe, 2008: 42).

Tanımlamadan kaynaklanan zorluğa rağmen Gözler-Kaplan da (2011: 320) kamu düzenini toplumun maddi ve dış düzeni olarak ifade ettikten sonra kamu düzeni kavramını, kamu 1 güvenliği, 1 kamu 1 huzuru 1 ve 1 kamu 1 sağlı̆̆ 1 kavramlarından 1 oluşan 1 "geleneksel 1 üçlü" 1 ile 1 tanımlanmaktadır. Bu kapsamda, kamu 1 düzeni 1 bireylerin 1 güvenlik, 1 huzur 1 ve 1 sağlik 1 içinde 1 yaşamaları durumu olarak ifade edilebilir.

Yukarıda da değinildiği gibi kamu düzeni, bireylerin umumi veya umuma açık yerlerde güvenlik, dirlik, esenlik ve sağlık içinde yaşamlarını sürdürmelerinin sağlanmasıdır. Bu minvalde, kamu düzeni, güvenlik, dirlik ve esenlik ve sağlık öğelerinden oluşan bir kavramdır (Günday, 2013: 292). Bu klasik unsurların yanı sıra modern anlayışta genel ahlak da kamu düzenin unsurları arasında yer almaktadır (Gözler ve Kaplan, 2011: 321).

Güvenlik geniş kapsamlı bir deyimdir (Gözübüyük ve Tan, 1999: 474). Güvenlik, bireylerin can ve mallarının kazalara karsı korunması demektir. Toplumda güvenliğin sağlanması, bireylerde kamu düzeninin varllğ 1 konusunda yeterli inancın yerleşebilmesi, ancak huzur ve güvenliğin sağlanmasıyla mümkündür. Yani devlete, topluma, kişilere ve mallara yönelik tehlike, kaza ve sabotajlara karsı gerekli güvenlik önlemleri alınmış olmalıdır ki, bireyler huzur ve güvenlik içinde yaşamını sürdürebilsin. Rastlantılara veya sadece kişilerin iyilik duygularına dayanarak toplumda güvenlik ve esenlik yaratılamaz. Tesadüfî bir huzur ortamı değil, bilinçli ve günün 24 saatinde sürdürülen güvenlik önlemleri esenlik ya da huzuru meydana getiren en büyük etkendir (Terzioğlu, 1982: 3).

Kamu huzuru olarak da ifade edebileceğimiz dirlik ve esenlik; toplumda, düzensizliğin, karışıklığın yokluğu, hayatın normal seyrini takip etmesi demektir. Kamu huzuru amaciyla kolluk, gürültü, duman, koku, toz gibi bireyleri rahatsız edecek, onların huzurunu bozacak faaliyetlere karşı gerekli tedbirleri alır (Gözler ve Kaplan, 2011: 166).

Kamu düzeninin bir öğesi olarak sağlık, her bir bireyin hastalıklardan kurtarılması anlamına gelmemektedir. Hastalıkların iyileştirilmesi ve böylece bireylerin hastalıklardan kurtarılması bir kamu hizmeti olan sağlı kamu hizmetinin konusu ve amacıdır (Günday, 2013: 292-293). Toplumun bulaşıcı ve salgin hastalıklardan uzak tutulmasının temin edilmesi suretiyle, toplumun sağlıklı bir biçimde yaşamını devam ettirmesinin sağlanmasına ilişkindir. $\mathrm{Bu}$ kavram ile ifade edilmek istenen, toplumun bir bütün olarak bulaşıcı ve salgın hastalıklar ile bu gibi hastalık tehlikelerinden uzak tutulmasıdır (Duran, 1982: 
255). Kolluğun unsurları içerisinde ifade edilen sağlık bireylerin bulaşıcı ve yaygın hastalıklardan korunması, toplumun sağlık koşulları içinde tutulmasıdır. Buna "genel sağlık" da denir (Gözübüyük ve Tan, 1999: 474).

Belirtildiği üzere kamu düzeninin ilk üç unsuru maddi ve dış düzeni ilgilendiren konulardır. Dış düzeni tehlikeye sokan, açığa vurulmuş ahlaki tutum ve davranışlar sınırlı da olsa idari 1 kolluğun 1 görevleri 1 içine 1 girmektedir. 1 İdari 1 kolluk, 1 bireylerin 1 düşünce 1 ve 1 inanç 1 alanlarını 1 düzenleyemez 1 (Gözübüyük 1 ve 1 Tan: 1 1999: 1 474).

Bir toplumda çoğunluğun kendilerini uymakla yükümlü saydıkları kurallara ahlak kuralı denmektedir (Şener, 2001: 31). Kolluğun genel ahlakın korunması ile ilgili görev ve yetkileri, kişilerin düşünce, inanç, duygu ve ülkü alanlarını düzenlemeyi ve denetlemeyi içermeyip, sadece bunların kamu düzenini bozacak şekilde dışa yansıması ile ortaya çıkan eylem ve durumları önlemek, engellemek ve kaldırmaktan ibarettir (Bucaktepe, 2008: 55).

\section{Kolluk Çeşitleri}

Kolluk kavramı hakkında yapılan tanımlamalar ve unsurlar kavramı idari kolluk ve adli kolluk olarak ayırmaktadır. Genellikle bu iki kavram birbirine karışmış durumdadır (Giritli vd., 2013: 741). Teşkilat merkezli olmayan bu ayrım, yapılan faaliyetlerin nitelik, amaç ve alanına göre yapılmıştır (Sever, 2013: 191).

Kolluk teşkilatları tek bir teşkilattan oluşmamaktadır. İhtiyaçlardan kaynaklanan farklı nedenlerle birçok farklı teşkilatlanma ortaya çıkmıştır, polis teşkilatından sahil güvenlik teşkilatına kadar çok sayıda kolluk teşkilatı mevcuttur (Hünler, 2010: 31).

Kolluk hizmeti ilk olarak "idari” ve "adli” olmak üzere ikiye ayrılmaktadır. Avrupa'da uzun yıllardır uygulanan bu sistemin, ülkemizde "adli kolluk yönetmeliği" ile uygulanmaya başlamış olsa da çeşitli sebeplerden dolayı halen tam anlamıyla hayata geçirilebildiğini söylemek zordur. Avrupa ülkelerinde adli kolluk uygulaması iki türlü görülmektedir. Belçika örneğinde "adli kolluk" İçişleri Bakanlığından ayrılmış ve Adalet Bakanlığına bağlı olarak örgütlenmiş; Fransa ve İtalya'da ise genel zabıta içerisinde ancak Cumhuriyet Savcılarının gözetim ve denetimi ile emir ve komutası altında kurulmuştur. Ülkemizde ise yalnız görev yönünden bir ayrım olup her iki kolluk da aynı kuruluşlar ve kişiler tarafından yürütülür. Yapılan görevin türüne göre emir makamı değişebilir (Çinar, 2014: 27). İdari kolluk ve adli kolluk ayrımı tanımlamalarının yapılması ve görev alanlarının tasnif edilmesi açısından önem taşımaktadır. İdari kolluk ve adli kolluk görev niteliği, amaçları açısından farklı olduğu gibi tabi oldukları hukuki mevzuatlar açısından da farklılıklar içermektedir. 
İdari kolluk, kamu düzenini güvenlik, esenlik, sağlık ve genel ahlakın korunması alanlarında sağlamaya ve korumaya çalışır. İdari kolluğun amacı kamunun düzen içinde yaşamasını sağlamaktır ve yapmış olduğu faaliyet önleyici, düzenleyici ve koruyucudur. İdarenin tüm faaliyetlerinde olduğu gibi kolluk alanında da amaç kamu yararı olmalıdır. İdari kolluk kamu düzenini sağlarken kamu yararı ile kişilerin hak ve özgürlükleri arasında denge sağlamalıdır. Doktrinde yapılan bir tanıma göre idari kolluk, belirli idari otoriteler tarafından kullanılan ve kamu düzenini sağlamak amacıyla kişi hürriyetlerine sınırlama ve yasaklar koyan bir müdahale şeklidir (Güner, 2011: 8).

Adli kolluk ya da adli zabıta deyimi ile "Kolluk ya da zabıta içerisinde adli görevleri yapmakla yükümlü bölüm" anlaşılmaktadır (Sarızeybek, 2002: 13). Adli kolluk suç işlendikten sonra, suçu ortaya çıkartmak, aydınlatmak ile suçlu veya suçluları tespit edip yakalamak ve adli makamlara teslim etmekle görevlidir (Sabah, 2008: 9). Dolayısıyla adli kolluğun görevleri, suç işlenildiğinin öğrenilmesiyle başlar. Adli kolluk görevi gereği suç oluşması durumunda, suçluları yakalama ve suçluların adli makamlar tarafından cezalandırılmasını sağlama amacını gütmektedir (Aydınlıŏlu, 2013: 29). Adli kolluk ile idari kolluk kavramları uygulamada birbirine karışmış durumdadır. Çünkü her iki tür kolluk faaliyetleri aynı makam ve personel tarafından yürütülmektedir (Giritli vd., 2013: 765).

Görev bakımından Kolluk Kuvvetini tanımlayacak olursak; kamu düzeninin sağlanması, kamu güvenliğinin kollanması ve korunması, suçluların bulunması, suçun önlenmesi, gerektiğinde zor kullanma yetkisine sahip olan ve yetkileri kanunlarla çerçevelendirilen bir devlet kuruluşudur. Diğer bir deyişle; emniyet ve asayişin sağlanması amacıyla kanunların verdiği görevleri yerine getiren, yetkiler kullanan icra ve inzibat kuvvetidir (Yenisey, 1991: 45).

3201 sayılı Emniyet Teşkilatı Kanunu'nun 3. maddesinde "Umumi zabıta silahlı bir kuvvet olan polis ve jandarmadır; hususi zabita ise, umumi zabita haricinde kalan ve mahsus kanunlarına göre teşekkül edip muayyen görevleri gören zabıta kuvvetleridir" ifadesi bulunmaktadır. Maddede de ifade edildiği gibi genel idari kolluk, "silahlı bir kuvvet olan polis ve jandarmadır". Bunlara "sahil güvenlik kuvvetleri" ve çarşı ve mahalle bekçileri”ni de ilave etmek gerekmektedir. Ayrıca Türk Silahlı Kuvvetleri de kolluk kuvveti olarak görevlendirilebilir (Gözler ve Kaplan, 2018: 289).

Jandarma, Fransız idari sistemi kaynaklı bir kavramdır. Fransızca "Gendarmerie" kelimesinin Türkçe' ye geçmiş hali Jandarmadır. Fransız kaynaklarında Jandarma, "Gens" ve "D'armes" kelimelerinin birleştirilmesiyle meydana gelmiş olup, "silahlı adamlar" demektir (Akman,1991: 59). Muhtelif kaynaklarda Jandarma kelimesinin Fransız menşeli olarak ifade edilse de, 
kavramın doğudan geldiğini gösteren kaynaklara da rastlamak mümkündür. Anadolu'nun bazı köylerinde "candarma", Rumeli'de "candırma" olarak telaffuz edilen bu kelimenin kökü olan "candar" kelimesi Farsça olup; "can” sağlık hayat, "dar" tutan-tutucu manasında kullanılmıştır, bu çerçevede değerlendirildiğinde kelimenin Fransızca olması ile beraber doğu menşeli bir kavram olduğu da ifade edilebilmektedir (Okçabol, 1938: 58).

Osmanlı İmparatorluğu'nda Yeni Çeri Birliği'nin 1826'da kaldırılmasıyla, Asakir-i-i Muntazâma Mansure, Asakir-i-i Muntazâma Hassa ve 1834, Asakir-i Redîfe askerî organları Anadolu ve Rumeli'nin bazı illerinde güvenliğin sağlanması ve kamu düzeninin korunması amaciyla kurulmuştur. Bu birlikler Jandarma'nın temelini oluşturmakla beraber, Jandarma terimi ilk defa 1839'da Tanzimat Fermanı'nın ilanını takip eden yıllarda yayımlanan tatbik kararnamelerinde görülür. Tanzimat Fermanının ilan edildiği 1839 yılı ile Asakirİ Zaptiye Nizamnamesi (Askerî Kolluk Tüzüğü)'nin yürürlüğe girdiği 14 Haziran günü birleştirilerek, 14 Haziran 1839 tarihi, Jandarma'nın kuruluş tarihi olarak kabul edilmiştir (JGK Resmi Web Sitesi, 2019).

Cumhuriyetin ilanı ile birlikte devlet kuruluşlarında köklü bir değişiklik ve yapılanma çalışması başlamıştır. Jandarma Teşkilatı ile ilgili olarak da Cumhuriyetin ilanından sonra mevzuat yönünden önemli değişiklikler yapılmıştır. 1930 yılında jandarmanın görev ve sorumluluklarını, hukuki statüsünü belirleyen 1706 sayılı Jandarma Kanunu kabul edilmiştir. Bu kanuni düzenleme ile bugünkü Jandarma Teşkilatının teşkilat yapısı kurulmuştur. 1930 yılına kadar jandarma teşkilatı ile ilgili toplu bir hukuki dayanak yok iken 1706 sayılı kanun ile jandarmayı ilgilendiren diğer kanun, yönetmelik ve talimatlar kaldırılmış, 1706 sayılı Jandarma Kanununun uygulanmasını göstermek üzere 25 Aralık 1937 tarihinde Jandarma Tüzüğü kabul edilmiştir (Akman, 1991: 66).

2803 sayılı Jandarma Teşkilat Görev ve Yetkileri Kanunu'nun 3. maddesine göre; "Türkiye Cumhuriyeti Jandarması, emniyet ve asayiş ile kamu düzeninin korunmasını sağlayan ve diğer kanunların ve Cumhurbaşkanlığ Kararnamelerinin verdiği görevleri yerine getiren, silahlı genel kolluk kuvvetidir" denilmektedir. 1706 sayılı Jandarma Kanununun 1. maddesinde ise "Türkiye Cumhuriyeti Jandarması umumi emniyet ve asayişi korumaya, kanun ve nizam hükümlerinin icrasını teminine ve bunlara müstenit hükümet emirlerini ifaya memur edilen bir inzibat kuvvetidir" hükmüne yer verilmiştir.

Jandarmanın görevleri mülki, adli ve askerî olmak üzere üç türlüdür. Mülki görevleri; emniyet ve asayiş ile kamu düzenini sağlamak, korumak ve kollamak, kaçakç1lı̆̆ men, takip ve tahkik etmek, suç işlenmesini önlemek için gerekli tedbirleri almak ve uygulamak, ceza infaz kurumları ve tutukevlerinin dış korunmalarını yapmak, adli ve askerî görevler dışında kalan ve diğer kanun ve 
nizam hükümlerinin icrası ile bunlara dayalı emir ve kararlarla jandarmaya verilen görevleri yapmaktır. Adli görevleri, işlenmiş suçlarla ilgili olarak kanunlarda belirtilen işlemleri yapmak ve bunlara ilişkin adli hizmetleri yerine getirmektir. Askerî görevleri ise kanunlarla ve Cumhurbaşkanlığ 1 kararnameleriyle verilen askerî hizmetleri yerine getirmektir (Akyılmaz vd., 2018: 572). Jandarma Genel Komutanlığı Türkiye yüzölçümünün yüzde 93' ü ve ülke nüfusunun yüzde 20 'sine hizmet vermektedir. 2018 yılı faaliyet raporunda açılanan personel dağılımını incelediğimizde 4.706 Subay, 1.465 Yedek Subay, 29.261 Astsubay,17.711 Uzman Jandarma, 69.779 Uzman Erbaş, 63.372 Erbaş/Er, 2.713 Devlet Memuru ve 908 İşçi olmak üzere toplam 189.915 personel mevcuduyla hizmet verdiği görülmektedir (JGK Resmi Web Sitesi, 2019).

\section{Jandarma Genel Komutanlığının Sivil Kolluk Sürecini Oluşturan Kanun Hükmünde Kararnameler}

15 Temmuz 2016’da, Pensilvanya'da bulunan FETÖ/PDY terör örgütü lideri Fetullah Gülen tarafindan verilen emirler doğrultusunda terör örgüt mensupları tarafından seçilmiş iktidarı devirmeye yönelik darbe ve işgal teşebbüsüne kalkışılmıştır. Türkiye'yi işgal etmek ve seçilmiş iktidarı devirmek amacıyla, devlet kademelerine sızmış olan terör örgütü üyeleri devlete ait olan savaş uçakları, helikopter, tank ve askerî araçlar ile devlet binalarının ve meclisi ele geçirmeye çalışmıştır. Bahse konu kalkışmaya karşı koyan vatandaşlarımızdan 248 kişi şehit olmuş ve 2196 vatandaşımız ise yaralanmıştır.

Türkiye Cumhuriyeti kurulduktan sonra demokratik bir sistemi seçmiş ve ondan sonra yürütme organını halk oylaması belirlemiştir. Cumhuriyet'in kuruluşundan günümüze kadarki süreçte Türkiye'nin dönem dönem darbelerle karşı karşıya kaldığını söylemek mümkündür. Bu darbelerin çoğu başarılı olurken 15 Temmuz 2016 tarihinde FETÖ/PDY terör örgütü tarafından gerçekleştirilen darbe girişimi halkın meydanlara inmesi sonucunda püskürtülmüş ve kalkışmanın başarısız olması sağlanmıştır. Darbeyi engellemeye çalışırken çok sayıda vatandaş hayatını kaybetmiştir. Bu darbe girişimi, Türk darbeler tarihinde halkın karşı çıkmasıyla engellenen ilk darbe girişimi olma özelliği taşımaktadır (Nisan ve Şeker, 2017: 70).

Darbe girişiminin bastırılmasının devamında Temmuz 2016 tarihinde Cumhurbaşkanı önce MGK'yı toplayarak görüşünü almış, ardından başkanlığında toplanan Bakanlar Kurulu Anayasanın mülga 120. maddesine dayanarak, yurdun tamamında 3 ay süre ile Olağanüstü Hal ilan etmiştir. $\mathrm{Bu}$ karar, 21 Temmuz 2016 tarihinde Türkiye Büyük Millet Meclisi'nin (TBMM) onayına sunulmuş ve 1116 sayılı Karar ile TBMM tarafından da aynen kabul edilerek onaylanmıştır. Bundan sonraki süreçte üçer aylık dönemler halinde 7 defa uzatılan OHAL dönemi, 17 Temmuz 2018 tarihine kadar sürmüştür. 
Olağanüstü halin (OHAL) ilan edildiği 20 Temmuz 2016 tarihinden 17 Temmuz 2018 tarihleri arasında toplam 1194 maddeden oluşan 30 adet OHAL Kanun Hükmünde Kararnamesi (KHK) yayınlanmış ve bunlarla mevzuat alanında toplam 1000 maddenin üzerinde yeni düzenleme yapılmıştır. Türkiye'de 1971'den başlamak üzere çıkartılan her KHK'ya bir sayı verilmiş ve çalışma yapılırken bu sayının 703 olduğu anlaşılmıştır. Sonuncusu 9 Temmuz 2018'de Resmî Gazetede ilan edilmiştir.

Jandarma Genel Komutanlığı'nın askerî kolluk olarak teşkilat yapısının değişikliğine ilk olarak 668 Sayılı KHK ile başlanılmıştır. İlk olarak, Türkiye Cumhuriyeti Jandarması tanımlamasında bulunan "silahlı askerî bir güvenlik ve kolluk kuvvetidir” ibaresi değiştirilmiştir.

668 say1l KHK'nın 5. maddesinde “10/3/1983 tarihli ve 2803 say11 Jandarma Teşkilat, Görev ve Yetkileri Kanununun 3 üncü maddesi aşağıdaki şekilde değiştirilmiştir.

"Türkiye Cumhuriyeti Jandarması, emniyet ve asayiş ile kamu düzeninin korunmasını sağlayan ve diğer kanunların verdiği görevleri yerine getiren silahlı genel kolluk kuvvetidir." hükmü ile jandarma tanımlamasında bulunan "askerî" ibaresi kaldırılmıştır.

Jandarma Genel Komutanlığının teşkilat bağlılığı ilgili değişiklikler yapılmadan önce 2803 Sayılı JTGKY' nın 4. maddesinde "Jandarma Genel Komutanlığı, Türk Silahlı Kuvvetlerinin bir parçası olup, Silahlı Kuvvetlerle ilgili görevleri, eğitim ve öğrenim bakımından Genelkurmay Başkanlığına, emniyet ve asayiş işleriyle diğer görev ve hizmetlerin ifası yönünden İçişleri Bakanlığına bağlıdır. Ancak Jandarma Genel Komutanı, Bakana karşı sorumludur." şeklinde açıklanarak jandarmanın organik bağının TSK yapısına bağl1 olduğu görülmekteydi. Bu çerçevede Jandarma Genel Komutanı MGK ve YAŞ toplantılarına katılarak askerî hiyerarşi çerçevesinde görev yapıyordu.

İlgili KHK’nın 6. maddesinde "2803 sayılı Kanunun 4. üncü maddesi aşağıdaki şekilde değiştirilmiştir. Jandarma Genel Komutanlı̆̆ İçişleri Bakanlığına bağlıdır." hükmü ile Jandarma Genel Komutanlığı'nın TSK ile bağl1lığı tamamen ortadan kaldırılmıştır. JGK, İçişleri bakanlığı bünyesinde EGM ile aynı statüde, bakanlığın bağlısı bir kurum olmuştur. Yapılan değişiklik sonrasında Jandarma Genel Komutanı' nın YAŞ ve MGK bünyesinde bulunan görevleri sona ermiş ayrıca askerî hiyerarşi çerçevesinde terfilerde etkisi tamamen ortadan kalkmışır.

Askerî kolluk sürecinde JGK'nin kuruluş yapısı ve konuşlanması; “Jandarma Genel Komutanlığı Teşkilâtı; görevin özelliği ve Türk Silahlı Kuvvetlerindeki esaslara uygun olarak kendi kuruluş ve kadrolarında gösterilir. Jandarma Genel 
Komutanlığının kuruluş ve kadrolarıyla konuş yerleri, Genelkurmay Başkanlığının görüşü alınarak İçişleri Bakanlığınca düzenlenir. Ancak seferberlik ve savaşta Kuvvet Komutanlıkları emrine girecek birliklerin kuruluş, kadro ve konuşlarının düzenlenmesinde Genelkurmay Başkanlığının onayı alınır." açılaması ile yetkinin sadece Genelkurmay Başkanlı̆̆ında olduğu görülmekte ve kuruluş yapısının TSK esaslarına göre düzenleneceği ifade edilmektedir.

686 Sayılı KHK'nın 7. maddesinde bulunan "2803 sayılı Kanunun 5 inci maddesi başlığıyla birlikte aşağıdaki şekilde değiştirilmiştir.

Kuruluş ve Teşkilat: Jandarma Genel Komutanlığının kuruluş ve kadrolarıyla konuş yerleri, İçişleri Bakanlığınca düzenlenir. Ancak sıkıyönetim, seferberlik ve savaşta Kuvvet Komutanlıkları emrine girecek birliklerin kuruluş ve kadrolarıyla konuş yerlerinin düzenlenmesinde Genelkurmay Başkanlığının görüşü alınır. Jandarma birliklerinin kuruluş ve konuşlarının düzenlenmesinde mülki taksimat esas alınır. Ancak geçici olarak birden çok ili içine alan bölge teşkilatı da kurulabilir. Bölge komutanı, bölge teşkilatının konuşlu bulunduğu ilin valisine karş1 sorumlu olarak görev yapar." hükmü ile JGK'nin teşkilat yapısının sadece İçişleri bakanlığınca düzenleneceği açıklanmıştır. Ayrıca kadro yapısının TSK esaslarına uygun olacağı ibaresi kaldırılarak artık askerî esasların kullanılmayacağ 1 ve sivil bir teşkilatlanma yapısı olacağı ortaya çıkmıştır.

JGK'nin kuruluş yapısına iliş̧kin yapılan yasal değişiklikle düzenlenen sivil belirleyici hüküm sonrasında, KHK'nın 8. maddesinde bulunan "2803 sayılı Kanunun $6 \mathrm{ncı}$ maddesi başlığıyla birlikte aşağıdaki şekilde değiştirilmiştir.

Jandarma Genel Komutanı: Jandarma Genel Komutanı tüm Jandarma Teşkilatının komutanıdır. Jandarma Genel Komutanı general rütbesini haiz olanlar arasından atanır. Jandarma Genel Komutanı, Teşkilatın sevk ve idaresinden, kanun ve nizam hükümlerinin icrasını sağlamaktan, bunlara dayalı olarak verilen emir ve kararların uygulanmasından sorumludur." ibaresi ile Jandarma Genel Komutanı'nın atanma şekli açıklanmıştır.

Yapılan düzenleme öncesindeki uygulamalar değerlendirildiğinde, askeri kolluk terfi sistemi kapsamında, Jandarma Genel Komutanı, KKK bünyesinde bulunan Orgeneral rütbesindeki generaller arasından atanmakta olduğundan, JGK.lığ 1 bünyesinde general rütbesi taşıyan subayların, Korgeneral rütbesinden Orgeneral rütbesine terfi etmelerinin mümkün olamadığı görülmektedir. Yapılan değişiklik ile Jandarma Genel Komutanı, jandarma teşkilatının kendi bünyesi içerisinden orgeneral rütbesi ile atanmaya başlanılmış ve askerî sistem ile olan bağın bu terfi sisteminin değişikliği sonlandırılması hedeflenmiştir. 
Son olarak 668 sayıl1 KHK'nın 21. ve 22 maddelerinde bulunan “b) Jandarma Teşkilatının tüm personeli başka hiçbir işleme gerek olmaksızın, yeni durumlarına göre görevlerine devam ederler. Mevcut fiili kadrolardan öğretim elemanlarına ilişsin olanlar bu Kanuna, diğerleri 190 sayılı Kanun Hükmünde Kararnamenin eki (1) sayılı cetveline İçişleri Bakanlığ bünyesinde Jandarma Genel Komutanlığı bölümü olarak eklenmiştir. Ayrıca Jandarma Hizmetleri Sinıfindan bir adet Orgeneral kadrosu ile dört adet Jandarma Genel Komutan Yardımcısı kadrosu ihdas edilmiştir." ve "14/7/1965 tarihli ve 657 sayılı Devlet Memurlar1 Kanununun 36 nc1 maddesine "VII - EMNIYET HIZMETLERİ SINIFI" başlıklı bendinden sonra gelmek üzere aşağıdaki bent eklenmiş ve sonraki bentler buna göre teselsül ettirilmiştir. "VIII- JANDARMA HIZMETLERİ SINIFI Bu sınıf Jandarma Genel Komutanlığı kadrolarında bulunan subay, astsubay ve uzman jandarmaları kapsar." hükümleri ile Jandarma teşkilat yapılanması, tamamen DMK kapsamına alınmış ve bir Jandarma Hizmetleri Sınıfi oluşturulmuştur. Oluşturulacak kadroların İçişleri bakanlığ bünyesinde olacağ 1 belirtilmiş ve JGK'nin TSK ile bağ açısında da tamamen sonlandırılmıştır.

Jandarma Genel Komutanlığının personel kaynağı askerî kolluk sürecinde Jandarma Okullar Komutanlığı bünyesinde kurulmuş olan askerî okullar ile karşılanıyordu. 2803 Sayılı kanun değiştirilmeden öncesinde personel kaynağı hakkında bulunan "Jandarma subay ve astsubaylarının kaynak ve yetiştirilmeleri ile terfi, izin, sicil ve ödül işlemleri 926 sayılı Türk Silahlı Kuvvetleri Personel Kanunu esaslarına göre yürütülür. Jandarma subay ve astsubayları duyulan ihtiyaca göre Genelkurmay Başkanlığının onayı alınmak kaydıyla sınıflara ayrılır. Jandarma Genel Komutanlığının kendi kaynaklarından karşılanamayan subay ve astsubay ihtiyacı kendi kuvvetleriyle ilişikleri saklı kalmak şartıyla Jandarma Genel Komutanlığının talebi, Genelkurmay Başkanlığının onayı ile Kuvvet Komutanlıklarından sağlanabilir." madde ile yetkinin Genel Kurmay Başkanlığında olduğu açıkça ifade ediliyordu.

Ayrıca, 1706 Sayılı Jandarma Kanunu'na göre, eski kanun ve nizamnamelerdeki subay kaynakları bütünüyle kaldırılmış ve jandarma subay ihtiyacının Harp Okulu mezunu subaylardan karşılanması esası getirilmiştir. İlk olarak 1935 yılında Harp Okulunu bitiren teğmenlerden 29 subay, jandarma sınıfına ayrılmıştır. Kara Harp Okulundan mezun jandarma subaylarına, mesleğin özelliklerine uygun bir eğitim ve öğretim verilmesi zorunluluğu karşısında Ağustos 1998'de Beytepe Jandarma Okullar Komutanlığına taşınmış olup, eğitim ve öğretimini burada sürdürmüştür (JOK, 2004: 1-13). Astsubayların eğitim seviyelerinin günün koşullarına uygun olarak yükseltilmesi ihtiyacı nedeniyle de, Genelkurmay Başkanlığı bünyesinde yapılan çalışma neticesinde diğer kuvvetlerle birlikte Jandarma Genel Komutanlı̆̆ ihtiyacını karşılayan astsubay okulunun süresi de 2003-2004 eğitim-öğretim yılından itibaren iki yıla 
çıkarılmıştır. Jandarma Astsubay Meslek Yüksek Okulu; Beytepe Jandarma Okullar Komutanlığı bünyesinde 2003-2004 eğitim ve öğretim yılında faaliyete başlamıştır (JOK, 2004: 1-13).

JGK' nın tamamen sivilleşmesi sonrasında personel kaynağı oluşturulması nosyonu askerî okullar statüsünden çıkarılmış ve YÖK bünyesinde kurulan Jandarma ve Sahil Güvenlik Akademisine verilmiştir.

669 Sayı11 KHK' nın 113. maddesinde bulunan '2803 sayılı Kanunun 13 üncü maddesinden sonra gelmek üzere aşağıdaki 13/A maddesi eklenmiştir.

Jandarma ve Sahil Güvenlik Teşkilatlarının subay ve astsubay ve diğer personel ihtiyacını karşılamak, ön lisans, lisans ve lisansüstü eğitim-öğretim, bilimsel araştırma, yayın yapmak üzere bünyesinde fakülte, enstitü, astsubay meslek yüksekokulları, eğitim ve araştırma merkezleri ve kurslar bulunan bir yükseköğretim kurumu olarak İçişleri Bakanlığına bağlı Jandarma ve Sahil Güvenlik Akademisi kurulmuştur.

Akademinin kuruluş, görev ve çalışma usulleri 4/11/1981 tarihli ve 2547 sayılı Yükseköğretim Kanunu hükümleri saklı olmak kaydıyla Yükseköğretim Kurulunun da görüşü alınarak İçişleri Bakanlığınca çıkarılan yönetmelikle belirlenir. Akademinin eğitim-öğretim ve yönetim işleri Akademi Başkanı tarafından yürütülür. Hizmetin gerektirdiği hallerde İçişleri Bakanının onayıyla, diğer birim ve kurullar da teşkil edilebilir." hükmü ile bahse konu husus detaylı olarak açıklanmıştır.

JSGA sivil bir eğitim anlayışı ile kolluk personelinin eğitimin lisans ve ön lisans seviyesinde YÖK ile bir bağ çerçevesinde yürütmektedir. KHK nın ilgili maddesinde de görüldüğü gibi yegâne yetki yine İçişleri Bakanlığındadır. Bu çerçevede yeni personel eğitiminde askerî kimlik ve kültür tamamen kaldırılmış ve eğitim müfredatının uygulanmasında sivil kolluk personelini eğitimi göz önünde tutularak yeni akademik kadroların ihdas edileceği açıklanmıştır.

JGK'nın askerî kolluk süresinde ikmal esasları TSK esaslarına uygun olarak karşılanıyordu. KHK öncesinden ikmal esasları, ilgili yönetmeliğin 19. Md. sinde "Jandarma Genel Komutanlığ 1 ikmal hizmetleriyle faaliyetlerine ait her türlü ihtiyaçlarım ve Milli Savunma Bakanlığınca sağlanacak silah ve mühimmatını imkân nispetinde Türk Silahlı Kuvvetleri standartlarına uygun olarak kendi bütçesinden karşılar." Genelkurmay Başkanlığınca lüzum görülecek hallerle seferberlik ve savaş halinde Kuvvet Komutanlıkları emrine, girecek jandarma birliklerinin her türlü ihtiyaçları (sefer stokları dâhil) emrine gireceği Kuvvet Komutanlıklarının standartlarına uygun olarak barıştan itibaren Milli Savunma Bakanlığınca sağlanır.” hükmü ile açıklanıyordu. 
676 Sayılı KHK'nın 17. maddesi “2803 sayılı Kanunun 19 uncu maddesinin birinci fikrasına aşağıdaki cümleler eklenmiştir. Jandarma Genel Komutanlığının ihtiyaçları, İçişleri Bakanlığı tarafından Milli Savunma Bakanlığına doğrudan teklif edilir. Bu ihtiyaçlar İçişleri Bakanlığının güvenlik önceliklerine göre değerlendirilir." ile değiştirilmiştir.

İlgili maddede de açıklandığı gibi JGK'nın TSK esaslarına göre olan ikmal edilmesi esası kaldırılmış ve İçişleri bakanlığının güvenlik önceliğine göre ikmal edileceği belirtilmiştir. JGK' nın sivil bir kolluk olarak güvenlik hizmetini İçişleri Bakanlığının esaslarına göre devam ettireceği açıkça ifade edilmiştir.

668 Sayılı KHK ile JGK personeli hakkında uygulanacak disiplin mevzuatı, TSK'ne ait olan mevzuattan ayrılmıştır.

682 Sayılı KHK'nın 1. maddesinde bulunan "Bu Kanun Hükmünde Kararnamenin amac1; Emniyet Genel Müdürlüğü, Jandarma Genel Komutanlığı ve Sahil Güvenlik Komutanlığı personeline ilişkin disiplinsizlik ve cezaları, disiplin amirlerini ve kurullarını, disiplin soruşturma usulü ile diğer ilgili hususları düzenlemektir."

Md. 2 "Bu Kanun Hükmünde Kararname;

a) Emniyet Genel Müdürlüğü teşkilatında çalışan her sınıftan memurları,

b) Jandarma Genel Komutanlığ1 ve Sahil Güvenlik Komutanlığ teşkilatlarında görev yapan subay, astsubay, sözleşmeli subay, sözleşmeli astsubay, uzman jandarma, uzman erbaş, sözleşmeli erbaş ve sözleşmeli erler ile diğer sınıflardaki memurları, kapsar.

Jandarma Genel Komutanlığı ve Sahil Güvenlik Komutanlığı emrine verilen yükümlü erbaş ve erler hakkında 31/1/2013 tarihli ve 6413 sayılı Türk Silahlı Kuvvetleri Disiplin Kanunu hükümleri uygulanır.” İfade ile disiplin soruşturma esaslarına dair hususlar düzenlenmiştir.

İlgili maddede JGK personeli ile EGM personelinin tabi olduğu disiplin esaslarının aynı olduğu görülmektedir. Soruşturma esasları her iki kurum personeli içinde aynı çerçevede yürütüleceği ifade edilmektedir. Sadece JGK emrine verilen yükümlü erbaş ve erler hakkında TSK Disiplin Kanunu hükümleri uygulanacağı belirtilmiştir. Yapılan bu değişiklik ile JGK' nın kurumsal olarak disiplin esasları askerî disiplin dışına çıkmış ve sadece sivil mevzuatlar sınırlarında bir disiplin anlayışı kazanmıştır. Ayrıca JGK'nın bu madde ile EGM ile eşdeğer bir sivil kurum olduğu açıkça ortaya konmuştur. 
Jandarmanın görev ve sorumluluk alanı askerî kolluk sürecinde "Jandarmanın genel olarak görev ve sorumluluk alanı; polis görev sahası dışı olup, bu alanlar il ve ilçe belediye hudutları haricinde kalan veya polis teşkilâtı bulunmayan yerlerdir. Jandarma, kendisine verilen görevlerin ifası ile ilgili olarak diğer güvenlik kuvvetleri ile işbirliği ve koordinasyonda bulunur. Jandarma veya Emniyet Teşkilâtı, kendi sorumluluk sahasında yetersiz kaldıkları veya kalacaklarının değerlendirilmesi halinde, mahalli mülki amirler tarafından birbirlerinin sorumluluk sahalarında geçici olarak görevlendirilebilirler. Jandarmanın diğer güvenlik kuvvetleriyle işbirliği ve koordinasyon esasları ve emir komuta ilişkileri yönetmelikle belirlenir." İfadesi ile açıklanmıştır. Madde de İçişleri bakanlığının sorumluluk alanın yetkisi hakkında tam bir yetki ifade edilmese de mülki amirlerin asayiş hizmeti çerçevesinde yetersiz kalma durumlarında geçici görevlendirme yetkisi olduğu belirtilmiştir.

Sivil kolluk yapılanması ile ilgili KHK'nın 52. maddesi ile “10/3/1983 tarihli ve 2803 sayılı Jandarma Teşkilat, Görev ve Yetkileri Kanununun 10 uncu maddesine birinci fikrasından sonra gelmek üzere aşağıdaki fikra eklenmiştir.

İl ve ilçelerdeki jandarma ve polis sorumluluk alanlarının sınırları, ilçelerde kaymakam, illerde vali veya görevlendireceği vali yardımcısı başkanlığında jandarma ve emniyet temsilcilerinin katılacağ bir komisyon tarafından belirlenir. Komisyon, vali veya kaymakamın çağrısı üzerine toplanır. Büyükşehir, il veya ilçe belediyesi kurulması, kaldırılması ya da kentleşme veya diğer sebeplerle sınırlarda değişiklik olması halinde, değişikliğin yürürlüğe girdiği tarihten itibaren en geç üç ay içerisinde sorumluluk alanları yeniden düzenlenir. Komisyon tarafından alman kararlar İçişleri Bakanının onayıyla yürürlüğe girer. Belirlenen sorumluluk alanlarının sınırları karara eklenen bir harita veya kroki üzerinde gösterilir.” yeni bir düzenleme yapılmıştır.

Eklenen yeni fikra ile görev ve sorumluluk alanın düzenlenmesi hususu tam olarak açıklanmıştır. Ayrıca görev ve sorumluluk alanın düzenlenmesi için kurulan komisyondan çıkacak sonuçlarda nihai onay yetkisinin İçişleri Bakanlığında olmasıyla JGK üzerinde tek yetkili merciinin sivil bir makam olduğu tekrar ortaya çıkmışırı.

\section{Jandarma Genel Komutanlığının Sivil Kolluk Yapısının Etkilerinin Değerlendirilmesi}

Jandarma Genel Komutanlığı' nın sivil kolluk olarak teşkilatlanması sonucu oluşan etkilerin belirlenmesi amaciyla 03.01.2019 tarihinde, Tokat İl Jandarma Komutanlığı personeline mülakat uygulamak için dilekçe ile başvurulmuştur. Ancak 27.02.2019 tarihinde JGK tarafindan gönderilen yazısı ile mülakat talebinin uygun görülmediği cevabı verilmiştir. Alınan ret cevabında uygun görülme nedeni açıklanmamasında dolayı CIMMER bilgi edinme birimine 
başvurulmuş ve ret cevabı tekrar alınmıştır. Her ne kadar yapılan müracaatlarda JGK' na toplanacak verilerin gizli bilgileri içermediği ve sadece akademik çalışmalarda kullanılacağı belirtilse de veri toplanılması amacıyla uygulanmak istenen mülakata izin verilmemiştir.

Yapılan başvurular sonrasında JGK'da aktif görev yapan personelden sivil kolluk yapılanmasının etkilerinin değerlendirilmesine dair mülakat yapılarak veri toplanamayacağı anlaşılmıştır. Saha verilerinin aktif görev yapan personelden toplanamayacağının anlaşılması üzerine JGK'dan sivil kolluk süreci içerisinde istifa etmiş veya emekli olmuş personele mülakat uygulanmasına karar verilmiştir. Sivil kolluk yapılanmasının etkilerinin tespit edilmesine dair somut bulgu ve önerilere ulaşabilmek adına, sivil kolluk sürecinde görev yapmış ve sonrasında müstafi veya emekli olmuş 20 personele 12 sorudan oluşan mülakat soruları sorularak görüşmeler yapılmıştır.

Görüşme yapılan 20 kişi JGK'nın teşkilat yapısındaki şartlar çerçevesinde, bulundukları rütbeler, görev süreleri, yöneticilik konumları ve en son görev yaptığı birliklere göre farklılık oluşturacak şekilde belirlenmiştir.

7 personelin görev süresi 6-10 y11, 8 personel 11-15 y1l, 1 personel 16-20 yıl ve 4 personel 20 yıl ve üstü olarak JGK da görev yapmıştır.

2 subay, 11 astsubay, 5 Uzman Jandarma Çavuş, 2 Uzman Erbaş rütbesindeki personelden oluşmaktadır.

17 personelin yöneticilik görevi varken, 3 personelin yöneticilik görevi bulunmamaktadır.

9 personel İl Jandarma Komutanlıklarında, 2 personel İlçe Jandarma Komutanlıklarında, 3 personel Jandarma Karakol Komutanlıklarında, 4 personel Komando Tabur Komutanlıklarında ve 2 personel Eğitim Birliklerinde son olarak görev yapmıştır.

\section{Adli, İdari ve Operasyonel Görevlere Etkisi}

Jandarma Genel Komutanlığı askerî kolluk sürecinde adli ve idari görevlerinin yanı sıra bir TSK bağlısı olarak operasyonel görevlerinde Genel Kurmay Başkanlığının direktif ve emirleri doğrultusunda görev yapıyordu. Sivil kolluk olarak teşkilat yapılanmasına geçilmesi sonrasında JGK, İçişleri Bakanlığının güvenlik ihtiyaçları karşılanması esası çerçevesinde görev önceliği tanımlandı ve TSK ile olan görev bağı tamamen sonlandırıldı. 
Görüşme yapılan emekli/müstafi personel ile yapılan mülakatta sivil bir kolluk olarak icra edilen görevler açısından etkilerinin değerlendirilmesinde elde edilen bulgularda;

Askerî kolluk süreci ile bir fark olmadığı,

Askerî kültürün devam etmesi sebebiyle görevlere yönelik değişikliğin tam olarak yaşanamadı $\breve{g}$,

Karar alma ve inisiyatif almada olumlu etkilerinin olduğu,

Görevlerin daha hızlı sonuçlanıp askerî bürokrasinin verdiği gecikmelerin olmadığ 1 ,

Görevler açısından sivil kolluk yapılanmasına adaptasyon sürecinin biraz daha süreceği, tespit edilmiştir.

\section{Teşkilat Yapısındaki Değişiklilere Etkisi}

Jandarma Genel Komutanlığı, cumhuriyet dönemindeki ilk kuruluşundan sivil yapılanmasına kadar "askerî silahlı bir kolluk kuvveti" olarak tanımlanmıştır. Bu askerî süreç içerisinde JGK'nın teşkilat yapısı Genel Kurmay Başkanlığının belirlediği esaslara göre düzenlenmiş ve bu teşkilatlanma düzeni askerî hiyerarşi kriterlerine göre yapılmıştır.

668 Sayılı KHK ile JGK tamamen İçişleri Bakanlığına bağlanmış ve JGK' nın teşkilat kadro düzenlemelerinin İçişleri Bakanlığının belirlediği esaslara göre yapılacağı hükme bağlanmıştır.

Görüşme yapılan emekli/müstafi personel ile yapılan mülakatta JGK' nın sivil bir kolluk olarak teşkilat yapısının değerlendirilmesinde elde edilen bulgularda;

Askerî kolluk süreci ile sivil kolluk sürecindeki teşkilat yapısının arasında bir fark olmadığı,

Yapılan değişikliğin sadece birliklerin tabelalarında, yazışma esaslarında ve k1yafet gibi esaslarda olduğunun görüldüğü,

Sivil yapılanmada teşkilat yapısının, mülki amirlere ve sivil otoriteye, askerî kurumlardan daha öncelikli ve hassas davranıldığ 1 ,

Yapılan teşkilat değişikliğin ast personele yansımadığ ${ }_{1}$ daha çok üstsubay rütbesi üstündeki personelin terfi ve atama gibi özlük hususlarına yansıdığı, 
JGK' nın içerisinde askerlik kültürünün devam etmesi sebebiyle, sivil otorite ile arasında uyuşmazlıklar yaşandığı,

Bu sivil teşkilatlanma yapısının pozitif bir göstergesi olarak vatandaş ile daha rahat olarak ilişki kurulduğu ve iç içe hareket ettiği,

Sivil teşkilatlanma ile yeni birimlerin kurularak, görev açısından bu yeni birimlerin olumlu katkılarının olduğu tespit edilmiştir.

\section{Askerlik Kültürünün Devamlılığına Etkisi}

Jandarma Genel Komutanlığı yıllardır "kanun ordusu" tanımlaması ile askerlik kültürü esaslarına göre teşkilatlanmıştır. JGK bünyesinde personel eğitiminden, ülkemize hizmetine kadar bu askerlik kültürü her zaman kendini göstermiştir. Görüşme yapılan emekli/müstafi personel ile yapılan mülakatta JGK' da sivil yapılanma sonrasında askerlik kültürünün devamlılığının değerlendirilmesinde elde edilen bulgularda;

Sivil teşkilatlanma yapısına adaptasyon sorunu yaşanması sebebiyle, üst birimler tarafından askerlik kültürünün kaybedilmemesi mantığılya, askerî kültürün temelini oluşturan yanaşık düzen uygulamalarının yoğun bir şekilde ast personele icra ettirildiği,

Askerlik kültürünün devam etmesi gerektiğinin düşünüldüğü,

Sivil yapılanma sonrası JGK bünyesine katılan personel ile askerlik kültürü ile yetişmiş personel arasında çatışmalar yaşandığ 1 ,

Sivil otorite altında askerlik kültürünün devamlılığının sorun oluşturduğu,

Askerlik kültürünün azalması veya tamamen ortadan kalkması sonucunda disiplin zafiyetinin ortaya çıkacağı, tespit edilmiştir.

\section{Sivil Kolluk Yapılanması Sonrası Eğitim Alan Yeni Personelin Oluşturduğu Etkiler}

Jandarma Genel Komutanlığ1 Subay, Astsubay, Uzman Jandarma Çavuş, Uzman Erbaş rütbelerindeki personelden oluşmaktadır. Askerî kolluk sürecinde personel yetiştirilmesinde Subay rütbesindeki personel Kara Harp Okulu mezunu subaydan Jandarma sınıfını seçenler Jandarma Okullar Komutanlığında aldıkları bir yıl süreli kurs ile teşkilat bünyesine katılmaktadır. Astsubay rütbesindeki personel Jandarma Astsubay Meslek Yüksek Okulunda aldıkları eğitim ile göreve hazır hale gelmektedir. Diğer rütbelerdeki personelde aynı askerlik mantığı ile yetiştirilmekte ve teşkilat bünyesinde görevlerine başlamaktadır. 
Sivil kolluk süreci çerçevesinde Jandarma Okullar Komutanlığı kapatılmıştır. Teşkilat bünyesinde görev yapacak personel 669 Sayılı KHK ile kurulan Jandarma ve Sahil Güvenlik Akademisinde yetiştirilmeye başlanmıştır. JSGA bir yükseköğretim kurumu gibi görev yapmakta ve eğitim vermektedir. Emniyet Genel Müdürlügünün personel yetiştirilmesinde Polis Akademisinin yaptı̆g 1 görevin aynısı icra etmektedir. Görüşme yapılan emekli/müstafi personel ile yapılan mülakatta JGK' na sivil bir kolluk olarak yapılanma sonrasında eğitim alarak katılan yeni personelin değerlendirilmesinde elde edilen bulgularda;

Personel seçiminde hassas davranılmadığı ve eğitim alarak katılan yeni personelde nitelik ve nicelik eksikliği olduğu,

JSGA da eğitim alıp teşkilat bünyesine katılan personelin mesleki aidiyet duygusundan uzak olduğu,

Mesleki olarak ilgisiz ve uzak oldukları,

Sivil kolluk süreci sonrasında ilk olarak teşkilat bünyesine katılan personelin eğitim sürelerinin kısa olmasının olumsuz etkilerinin olduğu,

Sivil kolluk süreci eğitim alan personel ile askerî kültür ile eğitim alıp görev yapan personel arasında çatışma ve sorunlar yaşandığ 1 , tespit edilmiştir.

\section{Disiplin Mevzuatına Etkisi}

Jandarma Genel Komutanllğı personeline, askerî kolluk sürecinde bir TSK bağlısı olarak disiplin açısından 3451 Sayılı İç Hizmet Kanunu, 6413 Sayılı TSK Disiplin Kanunu, 1632 Sayılı Askerî Ceza Kanunu ve 926 Sayılı Personel kanunu esasları uygulanıyordu.

668 Sayılı KHK ile JGK İçişleri Bakanlığına bağlanmış ve tamamen sivil otorite emrine girmiştir. 669 ve 682 Sayılı KHK'ler ile JGK disiplin açısından askerî mevzuattan tamamen koparılmıştır. 682 Sayılı Genel Kolluk Disiplin Hükümleri Hakkında Kanun Hükmünde Kararname ile JGK'ı personeli hakkında uygulanacak disiplin esasları detayları ile belirlenmiştir. Görüşme yapılan emekli/müstafi personel ile yapılan mülakatta JGK' nın sivil bir kolluk olarak teşkilat yapısının değerlendirilmesinde elde edilen bulgularda;

Askerî disiplin mevzuatı ile arasındaki farkın tam olarak anlaşılamadığı,

Amir konumundaki personelin yetkilerini artırdığg,

Askerî kültürün tam olarak kalkmaması sebebiyle yeni disiplin mevzuatının uygulanmasında sorunların yaşandığı, 
Yeni disiplin mevzuatının uygulanmasında yaşanan sorunların personeli olumsuz etkilediği, tespit edilmiştir.

Baskıcı bir mantık ile hazırlandığının düşünüldüğü bununda personelin özgüven, sayg1 ve sevgi değerlerini olumsuz etkilediği,

Bazı personelin ise askerî mantığın katı disiplin anlayışından uzak bir disiplin mevzuatı olduğunu düşündüklerinde olumlu buldukları, tespit edilmiştir.

\section{Özlük Hakları Açısından Etkisi}

JGK personelinin özlük hakları askerî kolluk sürecinde 926 Sayılı TSK Personel Kanunu hükümleri çerçevesinde düzenleniyordu. Sivil kolluk sürecinin başlaması ve JGK' nın İçişleri Bakanlığına bağlanması ile özlük haklarının yapılanmasında değişiklikler yapılmıştır. 668 Sayılı KHK' nin 21. ve 22. Md. leri ile değişikliler yapılarak JGK, EGM ile aynı şekilde 657 Sayılı Devlet Memurları Kanunu içerisinde bir hizmet sınıfı olarak (VIII - JANDARMA HİZMETLERİ SINIFI) yer almaya başlamıştır. Bu değişikliler ile JGK personelinin özlük işlemlerinin DMK hükümleri uygulanacağı ortaya çıkmıştır. Görüşme yapılan emekli/müstafi personel ile yapılan mülakatta JGK' nda meydana gelen sivil kolluk yapılanmasının özlük haklarına olan etkilerinin değerlendirilmesinde elde edilen bulgularda;

Herhangi bir değişiklik olmadığ 1 ,

Sivil yapılanma sonrasında yurt dışında görev yapma (Dışişleri Bakanlığı Misyon Koruma Görevleri) imkânlarının arttığı,

Herhangi bir değişiklik olmamasının sebebinin askerlik kültürünün devam etmesinin olduğu düşünüldüğü,

Özlük hakları kapsamında çalışma şartlarının yeni katılan personel ile daha rahat bir hale geleceği düşünülürken herhangi bir değişiklik olmadığı, tespit edilmiştir.

\section{Mesleki ve Kurumsal Aidiyet Açısından Etkisi}

Üniforma giyilerek ve bir disiplin altında icra edilen mesleklerde aidiyet duygusu görev yapan personelde kendini açıkça ortaya koymaktadır. JGK personeli de bu anlayış ile sivil kolluk sürecine kadar olan dönemde askerlik kültürünün oluşturduğu mesleki ve kurumsal aidiyet çerçevesinde görevini yapıyordu. Meydana gelen teşkilat yapısında ki sivil değişiklik ile artık iki kültür yapıs1 (sivil kültür-askerî kültür) JGK bünyesinde kendini göstermeye başlamıştır. Görüşme yapılan emekli/müstafi personel ile yapılan mülakatta JGK' 
nda meydana gelen sivil kolluk yapılanmasının mesleki ve kurumsal aidiyet açısından değerlendirilmesinde elde edilen bulgularda;

Askerlik kültürünün devam etmesinden dolayı aidiyet duygusunun bu çerçevede personelde kendini gösterdiği,

Sivil yapılanma sonrası katılan personelde aidiyet duygusunun eksik olarak görüldüğü,

Askerlik kültürünün tamamen ortadan kalkmasıly kurumsal aidiyetin tamamen zayıf bir duygu olacağı ve bununda görevlerin icrasında özverili çalışmayı düşüreceği,

JGK bünyesinde sivil kültür ve askerî kültür arasında yaşanan uyumsuzlukların aidiyet duygusunu olumsuz etkilediği,

Sivil yapılanmanın tam olarak sistemde kendini göstermesi ile personelin daha çok öncelik alıp yetkilerini daha rahat kullanacağı ve bununda aidiyet duygusunu kuvvetlendireceği, tespit edilmiştir.

\section{Emniyet ve Jandarma Teşkilatlarının Ayrı Görev Yapması Açısından Etkisi}

Sivil kolluk yapılanması ile ülkemizde güvenlik hizmetleri İçişleri Bakanlığı tek elinde tamamen toplanmıştır. Bu çerçevede ikili kolluk sistemi ile Polis şehir merkezleri esaslı ve Jandarma ise taşralarda olmak üzere görevini devam etmektedir. Ülkemizde bu çerçevede ikili kolluk sistemi kendini göstermektedir. Görüşme yapılan emekli/müstafi personel ile yapılan mülakatta İçişleri Bakanlığ 1 bünyesinde JGK ve EGM ayrı ayrı görev yapması açısından değerlendirilmesinde elde edilen bulgularda;

İki kurumun koordineli olarak çalışmasının güvenlik hizmetlerinde kaliteyi artıracağ 1 ,

İki ayrı kurum yerine tek çatı altında toplanılması gerektiği,

Farklılığın sadece çalışma sahaları olan mülki alanlarda (taşra-şehir) olduğu görev çerçevesinin bir farkı olmadığ için bu farkın ortadan kalkması gerektiği,

Kritik terör operasyonlarında müşterek yapılan görevlerin çok faydalı olup olumlu sonuçlar alındığ 1 ,

Emniyet personelinin JGK personeline göre daha profesyonel olduğu ve EGM'nin kurum olarak daha nitelikli teşkilatlandığı bunun JGK' da yansıtılması gerektiği 
Askerlik kültürünün devam ettiği sürece tek çatı altında görev yapılamayacağı, tespit edilmiştir.

\section{JGK’ da Rütbe ve Makam Değișikliği Olmaması Açısından Etkisi}

Jandarma Genel Komutanlığı sivil kolluk yapılanması ve İçişleri Bakanlığına bağlanması sonrasında kurum bünyesinde görev yapan personelin taşıdığı rütbeler ve teşkilatın meydana geldiği makam isimlerinde herhangi bir değişiklik meydana gelmemiştir. JGK' da değişiklik meydana gelmemesi askerlik kültürünün devamlılığına imkân vermiştir. Görüşme yapılan emekli/müstafi personel ile yapılan mülakatta İçişleri Bakanlığı bağlanan JGK' da herhangi bir rütbe ve makam değişikliği olmaması açısından değerlendirilmesinde elde edilen bulgularda;

Askerlik kültürünü devamı olduğu için bu öğelerde bir değişiklik olmaması gerektiği,

Oluşabilecek herhangi bir değişikliğin disiplin zafiyeti oluşturacağı,

Bu değişiklikler olmadığı sürece görev yapan personelin askerlik kültüründen uzaklaşamayıp sivil yapılanmaya adapte olmada sorun yaşayacağı,

Sivil otoritenin de bu değişikliler olmadığı sürece JGK'nın kadrosunda görev yapan personel ve yöneticiler ile sorunlar yaşayacağı, tespit edilmiştir.

\section{SONUÇ}

Devletin en önemli görevlerinden bir tanesi toplumun huzur ve güven içerisinde yaşayabilmesini temin etmektir. Devletin "kamu düzeninin sağlanması" olarak da ifade edebileceğimiz bu güven ve huzur ortamının tesisi için yürütmüş olduğu faaliyetlere kolluk faaliyetleri ve bu faaliyetlerin yerine getirilmesinde kullanılan insan gücüne de kolluk personeli adı verilmektedir. Kolluk, kamu düzenini sağlayabilmek için kamu düzenini bozma ihtimali olan her türlü hareketi denetim altında tutmakta ve yeri geldiğinde kişi hak ve hürriyetleri üzerinde sınırlayıcı işlemler tesis edebilmektedir. Kolluk hizmetlerinin sağlanabilmesi amacıyla devletin vatandaşlarına sağladığı diğer hizmetlerinde bulunan teşkilatları gibi kolluk hizmetleri içinde bir teşkilatlanmaya sahip olması gerekmektedir.

Kolluk genel olarak idari ve adli kolluk olmak üzere ikiye ayrılır. İdari kolluk "önleyici kolluk" veya "suç öncesi kolluk" olarak da tanılanabilmektedir. Bununla beraber adli kolluk ise, suç islenmesi halinde suçun ortaya çıkarılması, suçluların bulunarak adli makamlara teslim edilmesine esasında bir kolluk hizmetidir. Başka bir ifadeyle adli kolluğa "suç kolluğu" da denilmektedir. 
İçişleri Bakanlığına ülke genelinde, kamu düzenini korumak ve bozulan kamu tekrar temin edilmesi görevi verilmiştir. İçişleri Bakanı bu görevi bakanlığa bağlı genel kolluk kuruluşları olarak da adlandırılan Jandarma Genel Komutanlığı ve Emniyet Genel Müdürlüğü vasıtasıyla yerine getirmektedir. İdari teşkilatlanma yapımızda taşra teşkilatı olarak adlandırılan il ve ilçelerde ise İçişleri Bakanı'nın temsilcisi olarak görülen mülki amir olarak görev yapan "Vali ve Kaymakam" lar iç güvenliğin temin edilmesinden sorumlu sivil otoritelerdir. $\mathrm{Bu}$ iki kuruluşun; emniyet ve asayiş işleri ile diğer görev ve hizmetin ifası yönünden İçişleri Bakanlığı'na bağlılıkları esas alınmıştır. Bu nedenle mülki amirler görev yaptıkları bölgedeki kolluk teşkilatlarının amiri konumunda bulunmaktadırlar.

1839 yılında 2016 y1lına kadar askerî kolluk olarak görev yapan jandarma teşkilatı halk içerisinde de asker kimliği ile kabul edilmiş ve ülkenin en ücra noktalarında görev yaparak devletin temsilcisi olarak görülmüştür. JGK'da her ne kadar şu an için sivil bir yapılanma mevcut olsa da, yapılan bu çalışma için izin talebine gerekçe gösterilmeden alınan ret cevabı ile askerî görüşün halen sürdüğü ve bu askerî kültürün etkisi ile kapalı sistem bir çalışma mantığının JGK'da devam ettiği bunun neticesi olarak akademik bir çalışma için dahi veri toplanılmasına müsaade edilmediği belirlenmiştir. JGK tarafindan icra edilen görevlerde sivil yapılanma ile tam anlamıyla bir değişikliğin meydana gelmediği, sadece inisiyatif ve operasyonel görevlerde karar almada daha hızlı bir süreç işlediği askerî bürokrasinin biraz olsun azaldığ 1 sonucu elde edilmiştir. Bu çerçevede teşkilat yapısındaki sivil yapı değişikliğinin kurumsal olarak işleyişte hayata tam manasıyla geçmediği sadece yazışma, birliklerin tabelası ve kıyafet gibi dış unsurlarda meydana geldiği belirlenmiştir. Sistemsel değişikliğin meydana gelmesinin uzun bir zaman alacağı düşünülmektedir.

Sivil kolluk yapılanması ile kurulan JSGA'dan mezun olan ve teşkilat bünyesine yeni katılan personelin eğitim, mesleki bilgi ve görev yapmas1 açısından eksikleri olduğu ve sivil zihniyet ile yetişmiş bu personelin askerî kültür ile yetişmiş personel ile arasında sorunlar yaşadığı ve bu sorunların icra edilen görevleri olumsuz etkilediği elde edilen diğer bir sonuç olarak karşımıza çıkmaktadır. Ayrıca mesleki ve kurumsal aidiyet açısından askerî kültür ile bu aidiyet duygusunun devam edeceği, sivil kolluk zihniyetinin kurumsal olarak aidiyet duygusunu olumsuz etkilediği bununda sebebinin askerî anlayış ile sivil anlayış arasındaki uyumsuzluk olduğu değerlendirilmektedir.

Kaldırılan askerî disiplin mevzuatı sonrasında yürürlüğe konulan yeni disiplin mevzuatına uyum sağlanamadığı değerlendirilmektedir. Bunun sebebinin ise diğer sonuçlarda olduğu gibi teşkilat içerisinde çok uzun süren ve kalıcı etki bırakan askerî disiplin olduğu düşünülmektedir. 
JGK'nın her ne kadar sivil idare altına girmiş olsa da askerî kolluk sürecinde olduğu gibi kırsal mahrumiyet alanlarından görev yapmasının olumsuz etkileri olduğu değerlendirilmektedir. İçişleri Bakanlığg Bünyesinde JGK ve EGM'nin 2 ayrı kurum olarak görev yapması gerektiği lakin bu teşkilatların görev alanlarının tekrar gözden geçirilmesinin daha faydalı olacağı da elde edilen sonuçlar arasındadır. JGK sahip olduğu 177 yıllık askerî kimlik sonrasında sivil idare emri altına girmesiyle teşkilat yapısında fiziki değişikliler yaşansa da uzun yıllar sahip olduğu askerlik kültüründen tam olarak ayrılamadığı bu çalışmanın sonuçları arasında görülmektedir. JGK'da kullanılmaya devam eden rütbe ve makam isimleri dahi teşkilatta herhangi bir değişikliğin tam olarak meydana gelmediği bu nedenle askerî kültürün devam ettiğini değerlendirilmektedir.

JGK sivil kolluk yapılanmasına geçişi sonrasında yı1lar süren askerlik kültürünün verdiği emir komuta tarzı yönetim anlayışı sebebiyle icra edilen görevlerde bazı eksik hususların bulunduğu düşünülmektedir. Aktif görev yapan personelin halli hazırda askerlik kültürü ile emir komuta edilemeye çalışıldığ 1 bununda personelin görev yaparken kendilerini sivil - asker kimliği arasındaki bıraktığı bununda görevlerini olumsuz etkilediği kanaatine varılmıştır.

JGK her ne kadar sivil yapılanma içerisinde olsa da hali hazırda kullanmış olduğu kurumsal yönerge ve yönetmelikler askerî zihniyet içerisinde hazırlanmıştır. Bu çerçevede askerî zihniyetin ortadan kaldırılmasının zor olduğu gibi kurumun sivil bir anlayış ile görev yapmasının neredeyse imkânsız seviyede olduğu da değerlendirilmektedir. Bu anlayış devam ettiği sürece teşkilat içerisinde görev yapacak personel ikilemler yaşayacağ 1 ve buda icra edecekleri görevleri olumsuz etkileyeceği düşünülmektedir. 177 yıllık bir askerî süreci değiştirmek ne kadar mümkün olmasa da günümüz dünyasında görev yapan kolluk teşkilatları gibi sivil bir otorite emrinde JGK'nın da görev yapması ve bu şartlara uyum sağlaması gerektiği düşünülmektedir.

Ayrica JGK personelinin tamamen sivil otorite ile kurulan JSGA'dan yetişen personel den oluşmadığ 1 sürece askerî kültürün sonlanmasının uzun bir süre alacağı da aşikârdır. Bu sebeple JGK içerisinde sivil kültür ve askerî kültür arasında çatışma yaşanmaması amacıyla sivil otoritenin kendisini teşkilat içerisinde daha fazla hissettirmesi gerekli oluğu kanaati oluşmaktadır. Bunlarla beraber JGK'nın bu çalışmada aktif personelden veri toplanmasına izin vermemesi ile de gösterdiği gibi askerî kültürün kapalı sisteminden sıyrılıp vatandaş ile ilişkili, dışa dönük bir yüz edinip teşkilat içerisinde yapılacak çalışmalara izin vererek şeffaflığını göstermelidir.

Bu çerçeve de JGK yönetim kadrolarında bulunan askerî kökenli yöneticiler ile beraber yönetim kadrolarına İçişleri Bakanlığı bünyesinden bürokratların atanması ile sivil yapılanmaya daha hızlı uyum sağlanacağı düşünülmektedir. 
Bunun sonucu olarak askerî kültürün devam ettiği JGK'ya sivil kültürün girmesi ile çalışma ortamları daha dışa yönelik bir hal alıp, kapalı bir çalışma sisteminden çıkarak, şeffaf ve vatandaş nazarında daha kabul gören bir kurum halini alacağ 1 değerlendirilmektedir.

Bu çalışmanın eksik yönü JGK' da aktif görev yapan personel ile görüşmeler yapılarak veriler toplanamamasıdır. Ayrıca bu konu temelinde sivil yapılanmaya dair ilk çalışma olarak öncesinde yapılan bir çalışma olmaması sebebiyle, değişim sonrası oluşan etkiler hakkında mukayese yapılamamıştır. Bu konu temelinde çalışmak isteyen araştırmacıların özellikle JGK içerisinden bu çalışmada olduğu gibi her rütbeden ayrıca değişik birimlerinde görev yapan personelden veriler toplamaya çalışması ve alacağ 1 cevapların objektif olması hususunda hassas davranmaları gerekmektedir.

\section{KAYNAKÇA}

Akman, N. (1991), Yönetimde iç güvenlik ve jandarma, Genel Kurmay Basımevi.

Akyılmaz, B., Sezginer, M. ve Kaya, C. (2018), Türk idare hukuku, Savaş Yayınevi.

Aydınlığu, M. (2013), Türkiye'de adli kolluk birimlerinin sorunları ve çözüm önerileri, Yayınlanmamış Yüksek Lisans Tezi, Maltepe Üniversitesi, İstanbul.

Bucaktepe, A. (2008), Genel idari kolluk ve kolluk ilişkileri, [Yayınlanmamış Doktora Tezi]. Gazi Üniversitesi.

Çinar, Ş. (2014). Kamu düzeninin sağlanmasında iç güvenlik istihbaratının önemi, [Yayınlanmamış Doktora Tezi]. İstanbul Üniversitesi.

Duran, L. (1982), İdare hukuku ders notlarl, İstanbul.

Giritli, İ., Bilgen, P., Akgüner, T., Berk, K. (2013), İdare hukuku, Der Yayınları.

Gözler, K. ve Kaplan, G. (2011), Kısa idare hukuku, 1. Bask1, Ekin Kitabevi Yayınları.

Gözler, K. ve Kaplan, G. (2018), İdare hukukuna giriş, Ekin Basım Yayın Dağıtım.

Gözübüyük, Ş. ve Tan, T. (1999), İdare hukuku, 1. Bask1, Turhan Kitabevi.

Günday, M. (2013), İdare hukuku, 10. Baskı, İmaj Yayıncılık. 
Güner, S. (2011), Kolluğun zor ve silah kullanması, [Yayınlanmamış Yüksek Lisans Tezi]. İstanbul Kültür Üniversitesi.

Hünler, A. (2010), İç güvenlik hizmetlerinde özelleştirme ve 5188 Sayılı Kanun, [Yayımlanmamış Yüksek Lisans Tezi]. Ankara Üniversitesi.

JGK Resmi Web Sitesi (2009), 2018 faaliyet raporu, http://www.jandarma.gov.tr/duyurular/faaliyet_raporu/faaliyet_raporu_ 2018.html Erişimi Tarihi:15. 04. 2019.

JGK Resmi Web Sitesi (2009), Tarihçe, https://www.jandarma.gov.tr/tarihce, Erişim Tarihi: 31. 08. 2019.

Jandarma Okullar Komutanlığı, (2004). Jandarma taktiği I, Öğretim Başkanlığı Yayınları.

Kahraman, M. (2013), Güvenlik bilimine kavramsal ve terimsel bir yaklaşım, Polis Bilimleri Dergisi, 15 (4), 23-45.

Kıratl1, M. (1973), Koruyucu idari hizmetler, Türkiye ve Ortadoğu Amme İdaresi Enstitüsü Yayınları.

Nisan, F. ve Şeker, N. T. (2017), Demokrasiyi sekteye uğratan darbe haberlerinin çerçevelenmesi: 15 Temmuz 2016 darbe girişimi örneği, Trt Akademi Dergisi, 2 (3), 68-95.

Okçabol, D. (1938), Meslek tarihi, Polis Enstitüsü Yayınları.

Özalp, G. O. (2015), Avrasya askerî statülü kolluk kuvvetleri teşkilâtı, [Yayımlanmamış Yüksek Lisans Tezi]. Necmettin Erbakan Üniversitesi.

Sabah, A. (2008), Türkiye’ de adli kolluk uygulamaları, [Yayınlanmamış Yüksek Lisans Tezi]. Afyonkocatepe Üniversitesi.

Sarızeybek, E. (2002), Türkiye'de adli kolluk, [Yayınlanmamış Yüksek Lisans Tezi]. Celal Bayar Üniversitesi.

Sever, Ç. (2013), Kamusal faaliyetlerin özel kişilere gördürülmesi: Özel güvenlik ve özel sağllk, [Yayınlanmamış Doktora Tezi]. Ankara Üniversitesi.

Şener, E. (2001), Hukuk sözlüğ̈̈, Seçkin Yayınevi.

Terzioğlu, A. (1982), İdari kolluk hizmetleri, Jandarma Okullar Komutanlığ Yayını.

Yenisey, F. (1991), Hazırlık soruşturması ve polis, Beta Yayınları. 
Yıldırım, Ramazan (2010), İdare hukuku dersleri II, Mimoza Yayınları. http://www.mevzuat.gov.tr/MevzuatMetin/3.5.20169741.pdf _Erişim Tarihi:09.01.2019.

http://www.mevzuat.gov.tr/MevzuatMetin/1.3.3201.pdf Tarihi:12.01.2019.

,Erişim

http://www.resmîgazete.gov.tr/eskiler/2016/07/20160727M2..htm Erişim Tarihi:15.04.2019.

http://www.resmîgazete.gov.tr/eskiler/2016/07/20160731-5.htm _Erişim Tarihi:16.04.2019.

http://www.resmîgazete.gov.tr/eskiler/2016/10/20161029-5.htm „Erişim Tarihi: 17.04.2019.

http://www.resmîgazete.gov.tr/eskiler/2017/01/20170123-1.htm,Erişim Tarihi:19.04.2019. 